\title{
Long term forecasting of natural gas production
}

\author{
S. H. Mohr ${ }^{\text {a,* }}$ G. M. Evans ${ }^{\text {a }}$ \\ a School of Engineering, The University of Newcastle, University Drive, Callaghan, \\ NSW 2308, Australia
}

\begin{abstract}
Natural gas is an important energy source for power generation, a chemical feedstock and residential usage. It is important to analyse the future production of conventional and unconventional natural gas. Analysis of the literature determined conventional URR estimates of 10,700-18,300 EJ, and the unconventional gas URR estimates were determined to be 4,250-11,000 EJ. Six scenarios were assumed, with three STATIC where demand and supply do not interact and three Dynamic where it does. The projections indicate that world natural gas production will peak between 2025 and 2066 at 140-217 EJ/y (133-206 tcf/y). Natural gas resources are more abundant than some of the literature indicates.
\end{abstract}

Key words:

Natural gas URR, Peak natural gas, Natural gas production

* Corresponding author.

Email addresses: steve.mohr@uon.edu.au, Geoffrey.Evans@newcastle.edu.au (G. M. Evans). 


\section{Introduction}

Natural gas is a flammable gas consisting predominately of methane found naturally in basins around the world. There are two main categories of natural gas namely, conventional and unconventional natural gas. Unconventional natural gas includes, coal bed methane, shale gas, tight gas, aquifer gas, biogenic and methane hydrates. In particular, coal bed methane is natural gas produced from coal seams [1], likewise aquifer gas is from water aquifers [2], tight gas is natural gas trapped in sandstone formations with a permeability of $<0.1 \mathrm{mD}$ [3], shale gas is a poorly defined term referring to a gas that is from an organically rich and fine grained deposit [4], biogenic gas is natural gas generated at a shallow depth from the degradation of organic material [5], finally, methane hydrates is natural gas trapped in ice crystals [6]. Conventional natural gas is considered to be natural gas sourced from rocks that is not one of the previously mentioned unconventional natural gases. Natural gas does not include man-made synthetic gases (such as syngas) or a predominately methane gas produced from landfill sites or manure or decomposing vegetation.

Natural gas is widely used around the world for a variety of applications including: power generation, chemical industry feedstock, transportation and for residential use. Production in 2008 was $\sim 113 \mathrm{EJ} / \mathrm{y}(\sim 108 \mathrm{tcf} / \mathrm{y})[7,8]$ and consumption is expected to increase to $164 \mathrm{EJ} / \mathrm{y}$ (156 tcf/y) in 2035 [9]. Is this future consumption possible?

The importance of natural gas has resulted in eight long term projections of future natural gas production in the literature. Table A.1 has the forecasted peak year and rate of production along with the year the estimate was made. 
Table A.1 also shows the Ultimately Recoverable Resources ${ }^{\text {a }}$ (URR) values used in the projections. First the projection by Edwards [10] estimated that natural gas production would peak at $115 \mathrm{EJ} / \mathrm{y}$ in 2040, this projection is no longer valid due to current production currently at the forecasted peak production rate. With the exception of Zhang et al. [11] all of the remaining projections forecast natural gas will peak at or before $2021[5,12-16]$. The projection by Zhang et al. [11] forecasts a peak in 2030-35. The importance of natural gas, and the considerable amount of effort, time and money needed to replace natural gas with alternative means that it is critical to determine whether natural gas will peak in less than a decade or around 2030-35 (or a different date altogether).

The aim of this study is to determine when and at what rate natural gas production will peak. To achieve this first, a review of natural gas projections in the literature will be presented. Next, URR values for both conventional and unconventional natural gas will be estimated, by Low, BG and HigH values. Next the model used to create the natural gas projections will be described. Finally the natural gas projection will be presented and compared with literature studies and possible future implications will be discussed.

\section{Natural gas projections}

Conventional natural gas production for the world has been projected to peak between 2008 and 2040 [5,10,12-16]. The studies used Hubbert curves [1214,16], Generalised Bass model [15], constant decline rate [5] and unknown method believed to be a Hubbert curve [10]. Edwards [10] modelled world

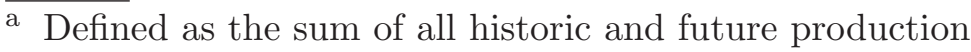


conventional gas production and assumed a URR of 12,200 EJ and a peak date of 2040 at $~ 115$ EJ/y. Al-Jarri and Startzman [12] also modelled world conventional production and used a URR of 7,400 EJ and a peak date of 2011 at $108 \mathrm{EJ} / \mathrm{y}$. Al-Fattah and Startzman [13] and Imam et al. [14] modelled conventional natural gas production by country and estimated a peak of 20142017 at $104 \mathrm{EJ} / \mathrm{y}$ with a URR of 10,560 EJ and a peak of 2019 at 93EJ/y with a URR of 9,680 EJ respectively. Guseo [15] modelled conventional world gas production by assuming a URR of 7,700 EJ determined a peak in 2008-2014 at $\sim 105$ EJ/y. Laherrère [16] estimated a URR of 10,500 EJ and projected a peak date of 2020 at 140 EJ/y. Campbell and Heaps [5] modelled natural gas production by country and determined the peak in 2021 at $113 \mathrm{EJ} / \mathrm{y}$. Recently, Zhang et al. (2010) modelled world natural gas production and used multicycle Hubbert curves to show it would peak in 2030-2035 at 137 EJ/y ( 130 tcf/y) [11]. Table A.1 summarises the conventional natural gas literature.

World unconventional gas production for the world has only been examined in the literature by Campbell and Heaps[5] and Laherrère[17]. In particular, Campbell and Heaps [5] projected unconventional gas as well as methane hydrates and biogenic gas and estimated a production to plateau in 2030 at 15 EJ/y. Laherrère [17] projected unconventional gas (including aquifer gas and methane hydrates) to peak around 2057 at $\sim 26 \mathrm{EJ} / \mathrm{y}$. 


\section{Literature ultimately recoverable resources estimates}

\subsection{Conventional natural gas URR}

The literature indicated that world conventional natural gas has a URR of 7,400-17,660 EJ, as shown in Tables A.1 and A.2. In addition, WEC 2010 estimate that the proved recoverable resources are 6,880 EJ which if combined with cumulative production of 2,860 EJ creates a URR estimate of 9,740 EJ. Three scenarios where chosen, which were similar to the estimate in Mohr (2010) [18]. The only difference from the previous estimate was that a newer version of the BGR report [19] was used here. In particular, the Low scenario assumed estimates in general from Campbell and Heaps [5] and Laherrère [17]. In places the estimate is from BGR [19] due to insufficient information. The Low URR estimate was 10,700 EJ (10,200 tcf), which is very similar to some of the lower URR estimates in the literature $[5,13,16]$. The High scenario assumed the estimate from BGR [19], which is the highest known URR estimate in the literature, with cumulative production added for countries that have ceased producing natural gas. The only change comes to the estimate for USA, it is indicated that the USA URR estimate by the BGR contains significant amounts of unconventional gas in it as well [20]. For this reason, a lower URR

estimate for the USA is selected instead of the BGR estimate. Finally the Best Guess (BG) scenario assumes the authors best estimate, and the source of the estimate for countries with >50 EJ is explained in Table A.3. The BG URR estimate assumed a URR of 12,900 EJ (12,300 tcf) and is similar to the estimate by Edwards [10]. 


\subsection{Unconventional natural gas URR}

The unconventional natural gas URR estimates are arranged by type. First coalbed methane is described, next shale gas and finally tight gas.

\subsubsection{Coalbed methane}

Kuuskraa and Stevens (2009) have recently estimated that the coalbed methane URR for the world by country is 870 EJ (830 tcf) [21]. Literature typically reports coalbed methane resources instead of URR values and a summary of these resource estimates are shown in Tables A.4 and A.5. As shown in these tables, the estimates for coal resources vary significantly from 3,100-25,200 EJ, however, if Scott and Balin's (2004) [22] high estimate is ignored then the range becomes 3,100-13,900 EJ. In this article it is assumed that the high estimate from Scott and Balin's is an outlier.

Due to the large range in the resource estimates three URR values will be used to in a bid to cover the large range. First, the Low scenario assumes the 870 EJ URR estimate from Kuuskraa and Stevens (2009) [21], Low is believed to represent an adequate minimum coalbed methane resource estimate. Next, the High URR estimate assumes Cramer et al. (2009) [23] low resource estimate of 5,070 EJ is completely recoverable. This should be viewed as an optimistic assumption as typical recovery fractions for coalbed methane range from 20 to $33 \%$ [24-26]. Finally, the BG assumed a URR of 2,533 EJ and was justified in Table A.6. 


\subsubsection{Shale gas}

Shale gas resources have been estimated for the world by region by Cramer et al. [23] and Rogner [27] as shown in Table A.7. The estimate by Cramer et al. was heavily influenced by the ground breaking work by Rogner. In North America however, several studies have estimated the ultimately recoverable resources e.g. [21,28-32] as shown in Table A.8. In particular, Kuuskraa and Stevens [21] indicate that North American resources are 5,400 EJ and the recoverable portion is $750 \mathrm{EJ}$, which indicates an overall recovery of around $15 \%$ of resources.

The URR was determined separately for North America and the rest of the world. The estimate for North America have been described in a previous paper [20] and was based on the estimates from [21,28-32] as shown in Table A.9. For the rest of the world all three URR scenarios assumed, the resource estimate by Rogner [27] was correct, and a 15\% recovery was assumed as this is the approximate overall recovery of resources as indicated in North America by Kuuskraa and Stevens. As Rogner [27] only has regions, the totals were split into various countries as explained in Table A.10. In the future, it is likely that the URR value assumed for the rest of the world will be considered too high or low. However it is impossible to reduce the uncertainty due to the limited amount of literature on shale gas resources in the world.

\subsubsection{Tight gas}

Tight gas reserves have been estimated for the world by Total to be between 740 and 1850 EJ, with the splits by region as shown in Table A.11 [33]. In addition worldwide tight gas resources have been determined to be approximately 8,000 EJ (see Table A.12) [23,27]. The Low scenario assumed the low 
reserve estimate by Total, the BG assumed the high reserve estimate of Total and the High scenario assumed that resource estimates by Cramer et al. and Rogner, and assumed a $15 \%$ recovery. The URR estimates used for the three scenarios are shown in Table A.13.

\subsubsection{Other sources}

Due to the limited and/or contradictory information on the resource size of other unconventional sources of natural gas, this article will examine only coalbed methane, shale gas and tight gas unconventional sources. It is reasonable to assume that in the future, production from methane hydrates and other unconventional sources may occur. It is likely that these resources will take a decade or more to be exploited.

\subsection{URR Summary}

A summary of the URR values selected is shown in Table 1

\section{Model Analysis}

The demand-production interaction model is described in [18]. Briefly, a URR is assumed for a given country ${ }^{\mathrm{b}}$, with production capability based on historical production for North Sea gas production. Production is further influenced by demand interactions.

$\overline{\mathrm{b}}$ which has a number of basins and fields 
Table 1

Conventional natural gas URR in ZJ for the world by country

\begin{tabular}{|c|c|c|c|c|c|c|c|c|c|c|c|c|c|}
\hline \multirow[b]{2}{*}{ CTY } & \multicolumn{3}{|c|}{ Conventional } & \multicolumn{3}{|c|}{$\mathrm{CBM}$} & \multicolumn{2}{|l|}{ Shale } & \multicolumn{2}{|l|}{ Tight } & \multicolumn{3}{|c|}{ Total } \\
\hline & $\mathrm{L}$ & $\mathrm{BG}$ & $\mathrm{H}$ & & $\mathrm{BG}$ & $\mathrm{H}$ & L BG & $\mathrm{H}$ & L BG & $\mathrm{H}$ & $\mathrm{L}$ & $B G$ & \\
\hline DZA & 0.23 & 0.23 & 0.29 & & & & & & $\begin{array}{ll}0.01 & 0.01\end{array}$ & 0.04 & 0.24 & 0.24 & \\
\hline NGA & 0.26 & 0.26 & 0.33 & & & & & & & 0.12 & 0.98 & 0.26 & \\
\hline Rest & 0.38 & 0.42 & 0.44 & 0.03 & 0.01 & 0.01 & 0.250 .25 & 0.25 & & 0.04 & 0.66 & 0.68 & 0.7 \\
\hline $\mathrm{AF}$ & 0.87 & 0.92 & 1.06 & 0.03 & $0.01 \mathrm{c}$ & 0.01 & $0.250 .25 \mathrm{c}$ & 0.25 & 0.010 .02 & 0.21 & 1.16 & 1.19 & \\
\hline AUS & 0.23 & 0.20 & 0.20 & 0.13 & 0.23 & 0.30 & $\begin{array}{lll}0.37 & 0.37\end{array}$ & 0.37 & $\begin{array}{lll}0.08 & 0.20\end{array}$ & 0.11 & 0.81 & 1.00 & \\
\hline $\mathrm{CHN}$ & 0.21 & 0.21 & 0.51 & 0.11 & 0.32 & 1.26 & $\begin{array}{lll}0.57 & 0.57\end{array}$ & 0.57 & $\begin{array}{lll}0.16 & 0.41\end{array}$ & 0.06 & 1.05 & 1.50 & \\
\hline IDN & 0.24 & 0.30 & 0.30 & 0.05 & 0.01 & 0.35 & & & $\begin{array}{ll}0.01 & 0.02\end{array}$ & 0.09 & 0.30 & 0.33 & 0.7 \\
\hline Rest & 0.53 & 0.63 & 0.65 & 0.02 & 0.02 & 0.02 & $0.05 \quad 0.05$ & 0.05 & & 0.03 & 0.6 & 0.70 & 0.7 \\
\hline $\mathrm{AS}$ & 1.21 & 1.34 & 1.66 & $0.31 \mathrm{C}$ & 0.571 & 1.93 & $0.990 .99 c$ & 0.99 & 0.250 .63 & 0.29 & 2.76 & 3.54 & \\
\hline NOR & 0.16 & 0.27 & 0.31 & & & & & & & & 0.16 & 0.27 & 0.3 \\
\hline Rest & 0.54 & 0.65 & 0.73 & 0.04 & 0.11 & 0.25 & 0.090 .09 & 0.09 & & 0.06 & 0.66 & 0.85 & \\
\hline EU & 0.70 & 0.92 & 1.04 & $0.04 C$ & $0.11 \mathrm{c}$ & 0.25 & 0.090 .090 & 0.09 & & 0.06 & 0.82 & 1.11 & 1. \\
\hline FSU & 2.31 & 3.45 & 7.62 & 0.251 & $1.45^{\circ}$ & 2.00 & 0.100 .100 & 0.10 & 0.090 .22 & 0.16 & 2.75 & 5.22 & 9.8 \\
\hline IRN & 1.21 & 1.50 & 1.50 & & & & & & & & 1.21 & 1.50 & \\
\hline QAT & 1.13 & 1.13 & 1.05 & & & & & & & & 1.13 & 1.13 & 1.0 \\
\hline SAU & 0.48 & 0.48 & 0.73 & & & & & & $0.05 \quad 0.13$ & 0.04 & 0.53 & 0.61 & 0.7 \\
\hline ARE & 0.18 & 0.31 & 0.31 & & & & & & & & 0.18 & 0.31 & 0.3 \\
\hline Rest & 0.33 & 0.50 & 0.52 & & & & $\begin{array}{lll}0.21 & 0.21\end{array}$ & 0.21 & & & 0.54 & 0.70 & \\
\hline $\mathrm{ME}$ & 3.33 & 3.93 & 4.12 & & & & 0.210 .210 & 0.21 & 0.050 .13 & 0.04 & 3.59 & 4.26 & 4.3 \\
\hline $\mathrm{CAN}$ & 0.33 & 0.33 & 0.64 & 0.10 & 0.18 & 0.79 & $\begin{array}{lll}0.10 & 0.43\end{array}$ & 0.68 & $\begin{array}{lll}0.15 & 0.21\end{array}$ & 0.33 & 0.67 & 1.15 & 2.4 \\
\hline USA & 1.31 & 1.31 & 1.31 & 0.15 & 0.17 & 0.21 & 0.330 .62 & 1.26 & $0.43 \quad 0.49$ & 0.66 & 2.22 & 2.60 & \\
\hline NA & 1.63 & 1.63 & 2.75 & 0.240 & 0.351 & 1.00 & 0.431 .051 & 1.93 & 0.580 .70 & 0.98 & 2.87 & 3.73 & $6.6^{\prime}$ \\
\hline BRA & 0.02 & 0.02 & 0.10 & & & & $0.34 \quad 0.34$ & 0.34 & & & 0.36 & 0.36 & 0.4 \\
\hline VEN & 0.24 & 0.24 & 0.33 & & & & & & & 0.07 & 0.24 & 0.24 & 0.4 \\
\hline Rest & 0.08 & 0.09 & 0.10 & 0.01 & - & 0.01 & & & & & 0.08 & 0.09 & \\
\hline SA & 0.65 & 0.73 & 0.89 & 0.01 & $-\mathrm{C}$ & 0.01 & 0.340 .340 & 0.34 & 0.010 .02 & 0.21 & 1.00 & 1.09 & 1.4 \\
\hline Tot. & 10.71 & 12.921 & 18.32 & 0.87 ? & 2.49 & 5.18 & 2.403 .023 & 3.91 & 0.981 .72 & 1.94 & 14.96 & 20.15 & \\
\hline
\end{tabular}




\subsection{Production}

Production of natural gas is determined from individual countries. Countries generally contain one or more natural gas basin, e.g. Carnarvon basin in Western Australia and the Bass Strait for Australia. These basins contain individual fields where natural gas is extracted. In order to project the production for a country, it is necessary to determine the production from basins and fields. The production of natural gas for the world, is determined as the sum of all the fields' productions in a basin, for all the basins in a country, and for all the countries in the world.

\subsubsection{Basins}

First, the total number of basins $n_{R_{T}}$ is inputted into the model, and the number of basin that have been placed on-line $n_{R}(t)$ is determined by the square root of the cumulative production. Mathematically this is:

$$
n_{R}(t)=\left\lceil\sqrt{\frac{Q(t)}{Q_{T}}}\right\rceil
$$

where $Q(t)$ is the cumulative production of the country and $Q_{T}$ is the URR of the country. At the start year it is assumed that one region is on-line. The URR of the i-th basin, $Q_{R_{T_{i}}}$, is calculated by:

$$
Q_{R_{T_{i}}}=Q_{\epsilon}(i)-Q_{\epsilon}(i-1)
$$

where $Q_{\epsilon}(i)$ is defined as: 


$$
Q_{\epsilon}=Q_{T} \frac{1-e^{\left(-r_{\epsilon}\left(i / n_{R_{T}}\right)^{2}\right)}}{1-e^{(-r \epsilon)}}
$$

where $r_{\epsilon}$ is a rate constant. This profile ensures that the size of the first basins are small, the middle ${ }^{\mathrm{c}}$ basins are large and finally the last basins are small. The equations developed were justified by examining North American oil production by states [18]. With the size and start year of the basin known the production for the basin is determined from these inputs as described below.

\subsection{Fields}

The production of a basin is determined from the production of individual fields in the basin. The number of fields on-line, URR of the fields and the production profile of the fields needs to be determined in order to calculate the production of the basin.

The number of fields on-line $n_{F}(t)$ was assumed to be proportional to the cumulative production of the basin $Q_{R}(t)$, that is:

$$
n_{F}(t)=\left\lceil r_{F} n_{F_{T}} \frac{Q_{R}(t)}{Q_{R_{T}}}\right\rceil
$$

where $r_{F}$ is a rate constant, $n_{F_{T}}$ is the total number of fields in the basin and $Q_{R_{T}}$ is the URR of the basin.

The URR of fields in a basin vary, hence the model has to change the size of the fields. The URR of a new field determined by assuming the cumulative discovery verses cumulative number of fields on-line follows a power law

$\overline{\mathrm{c}}$ ie ones around $n_{R_{T}} / 2$ 
relationship that is:

$$
\frac{Q_{D}(t)}{Q_{R_{T}}}=\left(\frac{n_{F}(t)}{n_{F_{T}}}\right)^{0.35}
$$

where $Q_{D}(t)$ is the cumulative URR in the first $n_{F}(t)$ fields. If the $i$-th field is brought on-line in year $Y_{F_{i}}$ then the URR of the $i$-th field $Q_{T_{i}}$ is determined by:

$$
Q_{T_{i}}=\frac{Q_{D}\left(Y_{F_{i}}\right)-Q_{D}\left(Y_{F_{i}}-1\right)}{n_{F}\left(Y_{F_{i}}\right)-n_{F}\left(Y_{F_{i}}-1\right)}
$$

The production profile of the field is assumed to, initially ramp up over 1 year to a maximum production level $F_{P_{i}}$, which is maintained until the year $t_{r_{i}}$ is reached where after it exponentially declines until production reaches $1 \%$ of the maximum production level as shown in Figure 1. The field profile can be expressed mathematically as [18]:

$$
P_{F_{i}}(t)= \begin{cases}0 & \text { if } t<Y_{F_{i}} \\ \frac{F_{P_{i}}}{t_{F}}\left(t-Y_{F_{i}}\right) & \text { if } Y_{F_{i}} \leq t<Y_{F_{i}}+t_{F} \\ F_{P_{i}} & \text { if } Y_{F_{i}}+t_{F} \leq t<t_{r_{i}} \\ F_{P_{i}} e^{\left(-\frac{F_{P_{i}}(1-0.01)}{Q_{r_{i}}}\left(t-t_{r_{i}}\right)\right)} & \text { if } t_{r_{i}} \leq t \leq t_{r_{i}}-\frac{\log (0.01) Q_{r_{i}}}{F_{P_{i}}(1-0.01)} \\ 0 & \text { if } t>t_{r_{i}}-\frac{\log (0.01) Q_{r_{i}}}{F_{P_{i}}(1-0.01)}\end{cases}
$$

with $t_{r_{i}}$ equal to:

$$
t_{r_{i}}=\frac{Q_{T_{i}}-Q_{r_{i}}}{F_{P_{i}}}+\frac{t_{F}}{2}+Y_{F_{i}}
$$


where $Q_{r-i}$ is the URR remaining when production begins to decline. The maximum production, $F_{P_{i}}$, and URR remaining when production declines, $Q_{r_{i}}$, are assumed to be proportional to the URR of the field.

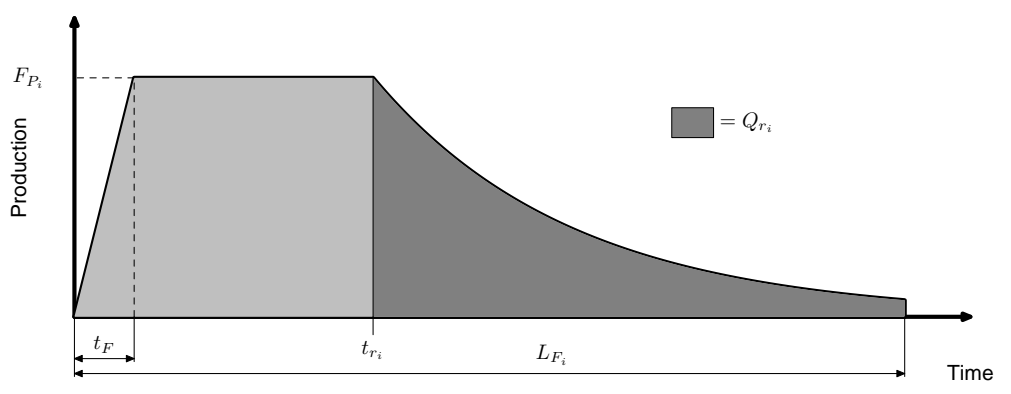

Fig. 1. Field profile assumed in the model [18]

The justification for these equations was based on analysis of the UK North Sea oil and gas statistics [18]. The equations above can be used to replicate the production from an oil or gas region (e.g. the UK component of the North Sea).

\subsection{Demand}

The demand can be determined in two ways Dynamic and Static, the Static demand is dependent on time only, whereas the dynamic demand is a modification of the static demand where natural gas also influence the demand. The simpler Static demand is described here, and the dynamic demand is described in the appendix.

The static demand for natural gas $D_{G}(t)$ is defined as:

$$
D_{G}(t)=f_{G}(t) \tilde{D}(t) p(t)
$$

where $p(t)$ is the world population, $\tilde{D}(t)$ is the per capita demand for fossil 
fuels and $f_{G}(t)$ is the natural gas fraction of fossil fuel demand. The population projection adopted in this study is the same as that used previously [18], i.e.

$$
p(t)=\frac{(10-0.82) \times 10^{9}}{\left[1+e^{(-0.046(t-2015.8))}\right]^{1 / 2}}+0.82 \times 10^{9} .
$$

The per capita demand projection used was identical to that in Mohr's thesis [18] namely:

$$
\tilde{D}(t)=\left\{\begin{array}{ll}
62 e^{(0.02502(t-1974))} & ; \text { if } t<1974 \\
62 & ; \text { if } t \geq 1974
\end{array} .\right.
$$

Finally the natural gas fraction of demand was determined previously [18] to be:

$$
f_{G}(t)=0.135 \tanh (0.03(t-1960))+0.135
$$

\section{Results and discussion}

The model projections are shown in Figures 2 and 3, and Tables 2 and 3 summarise the peak years and rates. The projections for each country and continents are presented in the electronic supplement. 
(a) Static Low

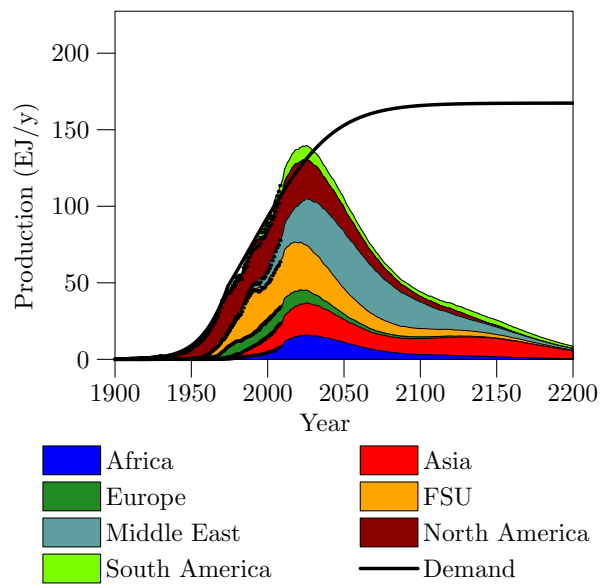

(c) Static BG

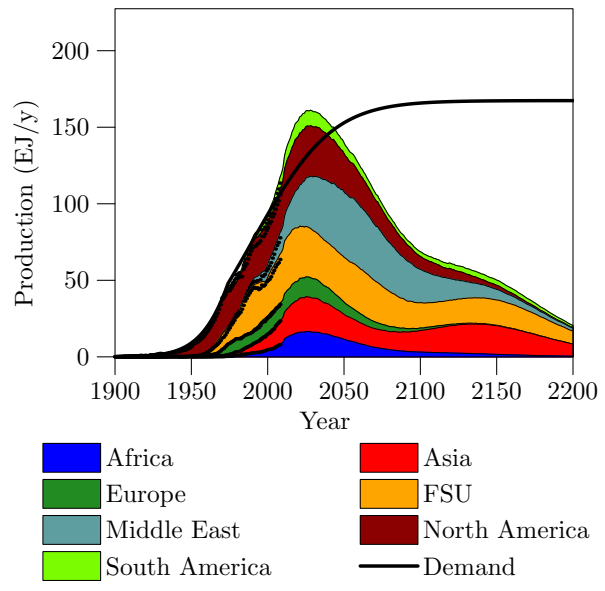

(e) Static High

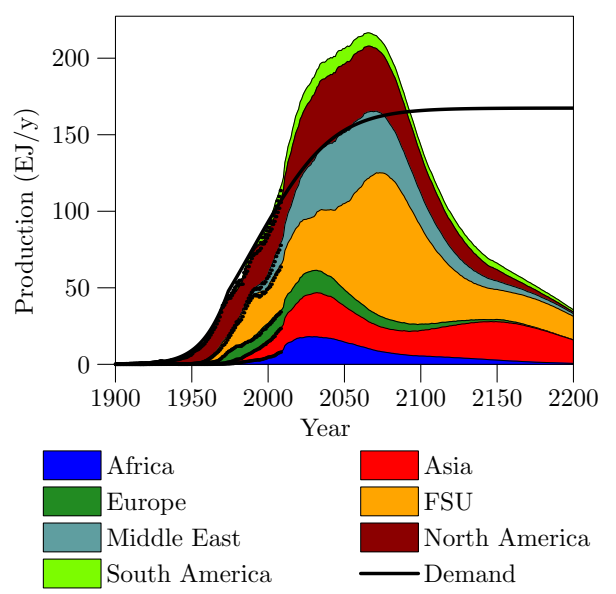

(b) Dynamic Low

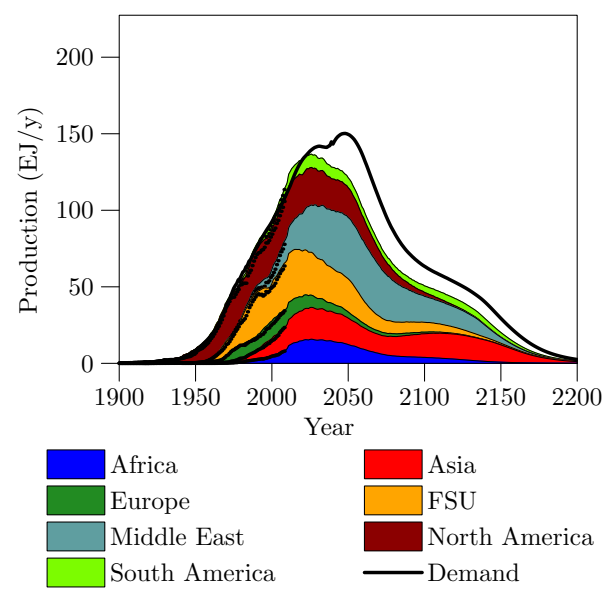

(d) Dynamic BG

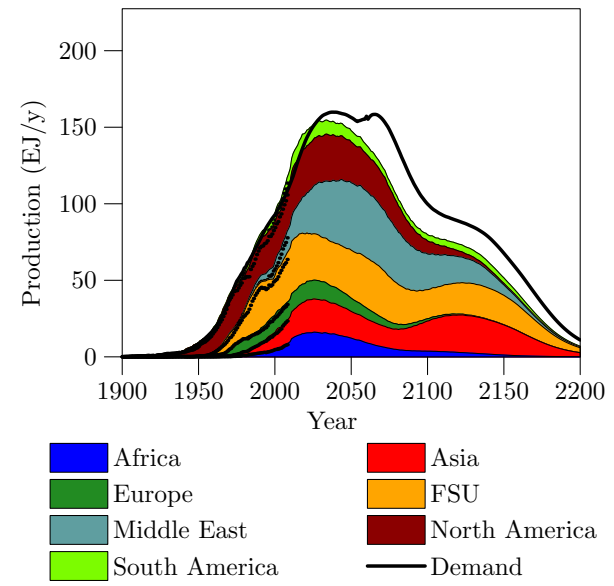

(f) Dynamic High

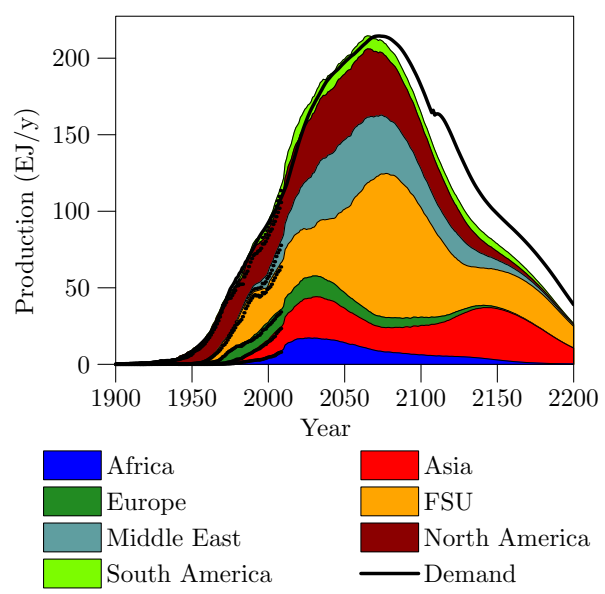

Fig. 2. Natural gas projections for the world by continent 
(a) Static Low

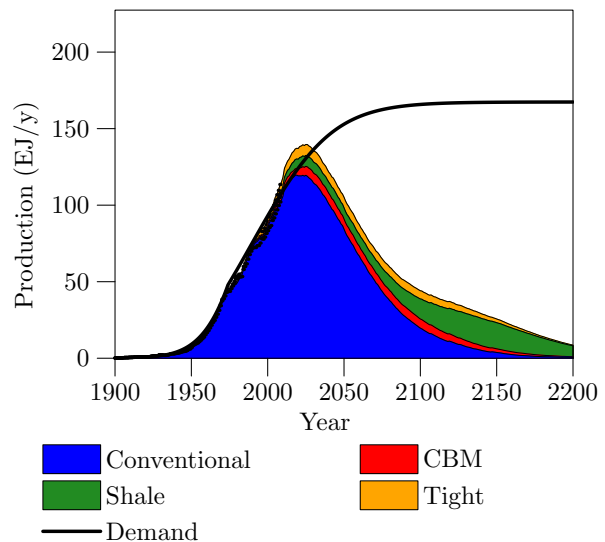

(c) Static BG

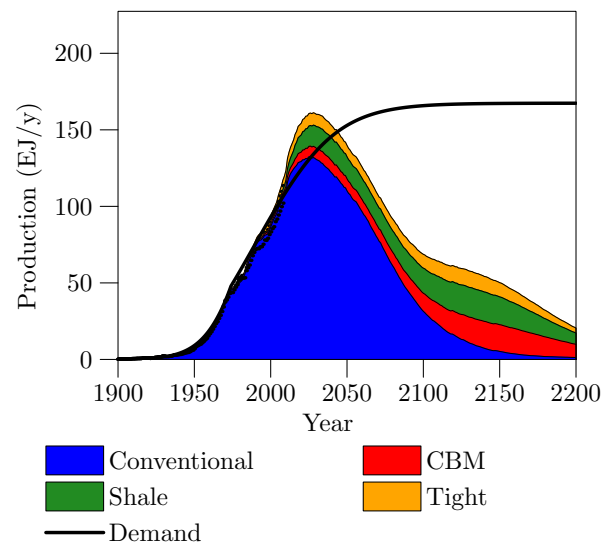

(e) Static High

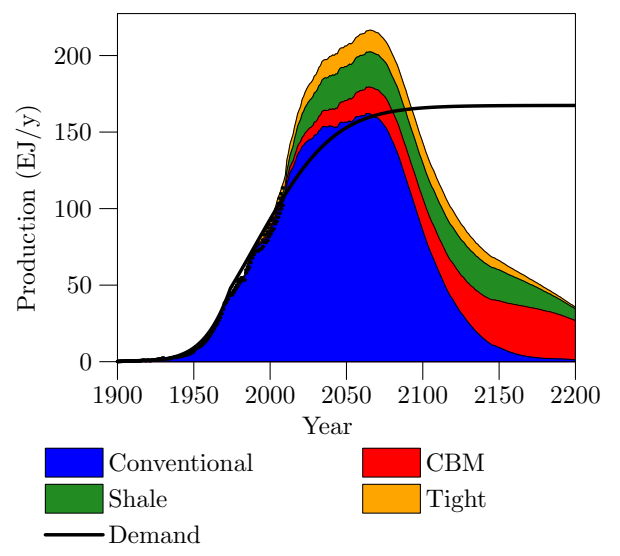

(b) Dynamic Low

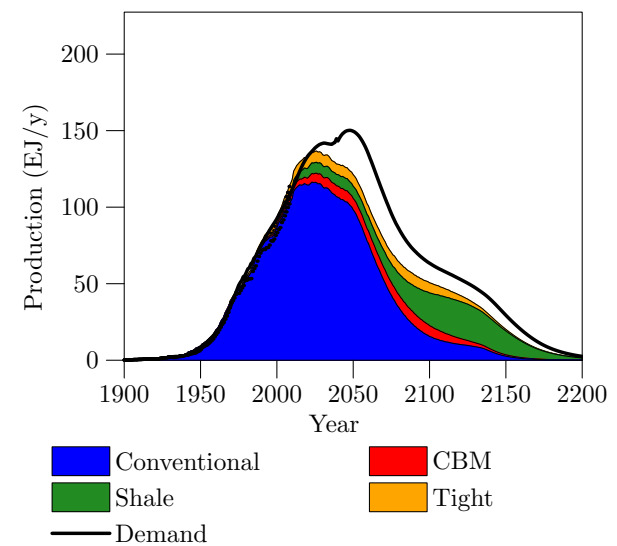

(d) Dynamic BG

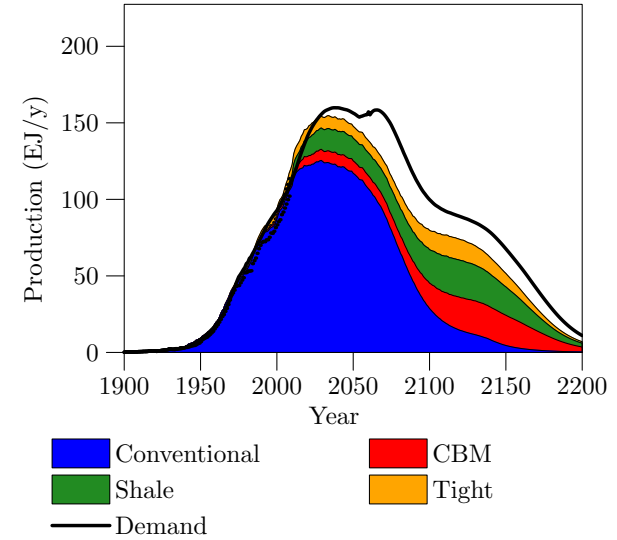

(f) Dynamic High

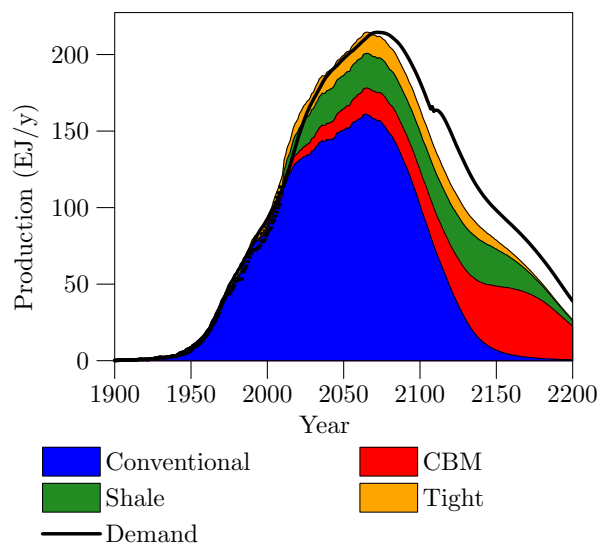

Fig. 3. Natural gas projections for the world by type 
Table 2

Natural gas peak years for the STATIC scenarios

\begin{tabular}{lcccccc}
\hline \multirow{2}{*}{ Type } & \multicolumn{3}{c}{ Peak Year } & \multicolumn{3}{c}{ Max Production } \\
& Low & BG & HiGH & Low & BG & HiGH \\
\hline Africa & 2026 & 2026 & 2027 & 15.8 & 16.6 & 18.1 \\
Asia & 2025 & 2025 & 2034 & 21.1 & 22.7 & 29.0 \\
Europe & 2004 & 2026 & 2028 & 11.6 & 13.0 & 15.0 \\
FSU & 2015 & 2016 & 2077 & 32.6 & 35.6 & 94.4 \\
Middle East & 2049 & 2049 & 2052 & 37.7 & 43.1 & 46.9 \\
North America & 2016 & 2023 & 2046 & 28.7 & 34.0 & 45.1 \\
South America & 2021 & 2022 & 2024 & 9.3 & 10.7 & 11.6 \\
Total & 2025 & 2028 & 2066 & 139.6 & 161.2 & 216.6 \\
\hline Conventional & 2019 & 2025 & 2066 & 119.6 & 132.4 & 162.2 \\
CBM & 2040 & 2141 & 2166 & 7.0 & 17.8 & 32.5 \\
Shale & 2136 & 2134 & 2117 & 18.0 & 19.5 & 23.5 \\
Tight & 2031 & 2128 & 2080 & 7.5 & 10.8 & 14.6 \\
Total & 2025 & 2028 & 2066 & 139.6 & 161.2 & 216.6 \\
\hline
\end{tabular}

The Static projections indicate that total natural gas production for the world will peak between 2025 and 2066 with a peak rate of 139.6-216.6 EJ/y (133-206 tcf/y). The StATiC CASE 1 \& 2 scenarios have a sharp peak with no continent dominating the production of natural gas. For the STATic CASE 3 scenario the FSU, Middle East and North America dominate the future supply of natural gas and the production remains in a broad plateau of above 200 EJ/y for $\sim 40$ years (2041-2080). The DYNAMIC projections indicate a similar peak rate and year with the peak estimated at 2026-2065 at 136.7-214.6 EJ/y (130-204 tcf/y). However the peak shapes are reversed with Dynamic CASE 1 \& 2 scenarios showing a broad plateau and Dynamic CASE 3 having a sharp peak. 
Table 3

Natural gas peak years for the DYNAMIC scenarios

\begin{tabular}{lcccccc}
\hline \multirow{2}{*}{ Type } & \multicolumn{3}{c}{ Peak Year } & \multicolumn{3}{c}{ Max Production } \\
& Low & BG & HiGH & Low & BG & HiGH \\
\hline Africa & 2026 & 2026 & 2027 & 15.7 & 16.1 & 17.2 \\
Asia & 2026 & 2123 & 2150 & 20.8 & 24.6 & 33.8 \\
Europe & 2004 & 2027 & 2028 & 11.8 & 12.4 & 13.9 \\
FSU & 2013 & 2013 & 2077 & 32.2 & 34.6 & 93.3 \\
Middle East & 2049 & 2056 & 2052 & 40.4 & 44.6 & 45.8 \\
North America & 2010 & 2018 & 2064 & 27.1 & 31.0 & 44.8 \\
South America & 2021 & 2023 & 2024 & 9.1 & 10.2 & 11.0 \\
Total & 2026 & 2034 & 2065 & 136.7 & 154.7 & 214.6 \\
\hline Conventional & 2023 & 2029 & 2065 & 116.4 & 125.5 & 161.0 \\
CBM & 2077 & 2130 & 2159 & 8.5 & 22.1 & 43.8 \\
Shale & 2117 & 2121 & 2133 & 24.3 & 24.3 & 28.1 \\
Tight & 2078 & 2113 & 2095 & 7.7 & 13.9 & 15.2 \\
Total & 2026 & 2034 & 2065 & 136.7 & 154.7 & 214.6 \\
\hline
\end{tabular}

The projections presented only partially confirm previous literature results. First, the projections $[12,13,15]$ that highlighted a conventional peak of 20082017 at $104-108 \mathrm{EJ} / \mathrm{y}$ are not replicated in any of the scenarios. Although Static CAse 1 peaks in 2019 the same as Imam et al. [14], Imam et al. projection estimates a peak rate of $93 \mathrm{EJ} / \mathrm{y}$ which is approximately $\sim 28 \mathrm{EJ} / \mathrm{y}$ lower than the Static Case 1 scenario. Both the Static and Dynamic CASE 1 scenarios, which indicate a peak in 2019 and 2023 at 120 and 116 EJ/y respectively agree well with the projection by Campbell and Heaps [5] who estimated a peak in 2021 at $113 \mathrm{EJ} / \mathrm{y}$. This result is unsurprising given that the URR values assumed for CASE 1 were based on Campbell and Heaps [5] estimate, but does to an extent validate the empirical modelling technique 
employed by Campbell and Heaps. Finally Static CASE 2 projection of a peak in 2025 at $132.4 \mathrm{EJ} / \mathrm{y}$ is reasonably similar to that of Zhang et al. [11] and Laherrère [16] who estimated a peak in 2030-35 and 2020 at 137 and $140 \mathrm{EJ} / \mathrm{y}$ respectively. No literature estimate could be found that indicated that conventional natural gas production could peak around 2065, despite the Static and Dynamic CASE 3 scenarios highlight that this is probable if the URR estimate from the well respected BGR institute is correct.

The demand assumed here is for the world, which requires large deposits of natural gas do not become stranded. It is possible that future bottlenecks may occur if adequate LNG shipping terminal and natural gas pipelines are not built. In particular, infrastructure such as the Turkey to Austria pipeline is necessary to ensure that Middle East natural gas production continues to grow and to provide Europe with a secure source of natural gas should Russia and Former Soviet Union countries continue to have disagreements over the price of natural gas.

The North American market is an important gas region due to the current shale boom, and will be discussed. The shale gas production in North America, is projected to underpin most of the future growth to North American gas production. Canada is currently dependent on natural gas to exploit its natural bitumen resources ${ }^{\mathrm{d}}$. It is projected that natural gas production will peak sometime between 2010 and 2064, at 27.1-44.8 EJ/y with the CASE 2 projections indicating a peak in 2018 and 2023 at 31 and $34 \mathrm{EJ} / \mathrm{J}$ respectively. It is unlikely that South America will be able to export much natural gas, so it is important that Canada and USA users and governments manage the long term use of natural gas.

d In the long term it would make sense to gasify mined natural bitumen to create a synthetic gas to extract the larger in-situ resources 


\section{Conclusion}

The Ultimately recoverable resources for conventional and unconventional natural gas for each country was determined. The URR was determined to be 10,700-18,300 EJ for conventional sources and 4,250-11,000 EJ for unconventional sources (coalbed methane, tight and shale gas). The conventional natural gas resources are dominated by Iran, Qatar, FSU and USA with considerable contributions from other nations. A demand-production model [18] was used to create six natural gas projections, STATIC projections have no production and demand interactions and DYNAMIC projections have interactions. The projections by Laherrère[16], Campbell and Heaps [5] and Zhang et al. [11] are broadly confirmed by CASE 1 and CASE 2 however, no literature estimates are as optimistic as the CASE 3 projections.

\section{$7 \quad$ Electronic Supplement}

The Electronic Supplementary contains the projections of all countries, and the constants used in the model.

\section{References}

[1] Energy Information Administration, Glossary, 〈www.eia.doe.gov/glossary/index.html〉 2010 [13.10.10]

[2] Doherty, MG, Unconventional natural gas resources, Proceedings of the Annual Gas Processors Association Convention, volume 61, 22-28. 
[3] Fletcher, S, Unconventional gas vital to US supply, Oil and Gas Journal, 2005;103(8):20-25

[4] Rokosh, CD, Pwlowicz, JG, Berhane, H, Anderson, SDA, and Beaton, AP, What is shale gas? An introduction to shale-gas geology in Alberta, Energy Resources Conservation Board, Alberta Geological Survey, Open File Report 2008-09, 2009.

[5] Campbell CJ, Heaps S, An Atlas of Oil and Gas Depletion, $2^{\text {nd }}$ ed. Jeremy Mills Publishing Limited, 2009

[6] Collett, TS, Natural gas hydrates - Vast resources, uncertain future, United States Geological Survey Fact Sheet, FS-021-01, 2001 〈http://pubs.usgs.gov/fs/fs021-01〉 [19.08.09]

[7] EIA International Energy Statistics, EIA website: 〈http://tonto.eia.doe.gov/cfapps/ipdbproject/IEDIndex3.cfm〉 [10,01,11]; 2011

[8] BP Statistical review of World energy, BP website: 〈http://www.bp.com/statisticalreview〉; 2010 [20.07.10]

[9] EIA, International Energy Outlook 2010, EIA website 〈http://www.eia.doe.gov/oiaf/ieo/〉 [10,01,11]; July 2010

[10] Edwards, JD, Crude oil and alternative energy production forecasts for the twenty-first century: the end of the hydrocarbon era, AAPG Bulletin, 1997;81(8):1292-1305

[11] Zhang J, Sun Z, Zhang Y, Sun Y, Nafi T, Risk-opportunity analysis and production peak forecasting on world conventional oil and gas perspectives, Petroleum Science, 7(1) 136-146, 2010

[12] Al-Jarri AS, Startzman RA, Worldwide petroleum-liquid supply and demand, Journal of Petroleum Technology, 1997;49(12):1329-1338 
[13] Al-Fattah SM, Startzman RA, Forecasting world natural gas supply, Journal of Petroleum Technology, 2000;52(5):62-72

[14] Imam A, Startzman RA, Barrufet MA, Multicyclic Hubbert model shows global conventional gas output peaking in 2019, Oil and Gas Journal, 2004;102:31:2028

[15] Guseo R, How much natural gas is there? Depletion risk and supply security modelling, 〈www.homes.stat.unipd.it/guseo/ngastfschr1.pdf〉 ; 2006 [18.08.09]

[16] Laherrère JH, Etat des reserves de gaz des pays exportateurs vers l'Europe, Club of Nice, 〈http://www.iehei.org/Club_de_Nice/2007/〉; 2007 [14.01.10]

[17] Laherrère JH, Oil and Gas: What Future?, Groningen Annual Energy Convention, 〈http://www.oilcrisis.com/Laherrere/groningen.pdf $\rangle ; 2006$ [24.09.08]

[18] Mohr SH, Projection of World Fossil Fuel Production with Supply and Demand Interactions, PhD thesis, the University of Newcastle Australia, 2010. 〈http://dl.dropbox.com/u/8223301/Steve\%20Mohr\%20Thesis.pdf〉

[19] Rempel H, Schmidt S, and Schwarz-Schampera U, Reserves, Resources and Availability of Energy Resources 2009, Technical report, Bundesanstalt für Geowissenschaften und Rohstoffe, BGR website 〈www.bgr.bund.de〉; 2009 $[26.10 .10]$

[20] Mohr SH and Evans GM, Shale gas changes N. American gas production projections, Oil and Gas Journal, 108(27), 60-64, 2010.

[21] Kuuskra, VA and Stevens SH, Worldwide gas shales and unconventional gas: A status report. In United Nations Climate Change Conference, COP15, Copenhagen, Denmark, 2009.

[22] Scott AR, and Balin DF, Preliminary assessment of worldwide coalbed methane resources, In Annual meeting of AAPG, 2004 
[23] Cramer B, Andruleit H, Rempel H, Babies H, Schlömer S, Schmidt S, Schwarzschampera U, Ochmann N, Meßner J, Rehder S, Ebenhöch G, Westphale E, Benitz U, Holding W, Berner U, Bönnemann C, Franke D, Gerling P, Keppler H, Krüger M, Ostertag-Henning C, Pfeiffer B, Pletsch T, Teichert B, Tischner T, Energierohstoffe 2009 reserven, ressourcen, verfügbarkeit. Technical report, Federal Institute for Geosciences and Natural Resources (BGR)

[24] DPI, Coal Seam Methane in NSW, NSW Department of Primary Industries website

〈www.dpi.nsw.gov.au/minerals/geological/overview/regional/sedimentary-basins/methanensw $\rangle$ [04.05.07], 2005

[25] Soot PM, Method forecasts coalbed methane production, Oil and Gas Journal, $89(43) 52-54,1991$

[26] Stringham

G, Canadian natural gas outlook, Canadian Association of Petroleum Producers (CAPP), CAPP website $\langle$ www.capp.ca/raw.asp? $=1 \& d t=P D F \& d n=110467\rangle$ [21.05.07], 2007

[27] Rogner H-H, An Assessment of world hydrocarbon resources, Annual Review of Energy and Environment, 22, 217-262, 1997.

[28] Theal C, The Shale Gas Revolution: The Bear Market Balancing Act. May 20th, $2009 \quad$ Tristone capital presentation 〈https://research.tristonecapital.com/CSUG_AGM_20May09.pdf〉 [25.05.10]

[29] FERC, Federal Energy Regulatory Commission, Natural Gas Markets: National Overview, May 2010 FERC website 〈http://www.ferc.gov/market-oversight/mkt-gas/overview.asp〉 $[01.06 .10]$

[30] Dawson FM, Cross Canada Check Up Unconventional Gas Emerging Opportunities and Status of Activity, Canadian Society for 
Unconventional Gas (CSUG) Technical Luncheon, May 12, 2010 CSUG website 〈http://www.csug.ca/images/Technical_Luncheons/Presentations/2010/MDawson_AGM2010.pdf〉 $[26.05 .10]$

[31] Henning S, Shale Gas Resources and Development, IRR's Inaugural Shale Gas Briefing, Brisbane March 30. 2010

[32] Skipper K, Status of Global Shale Gas Developments, with Particular Emphasis of North America, IRR's Inaugural Shale Gas Briefing, Brisbane March 30. 2010

[33] Total, Tight gas reservoirs, Total Worldwide, The Know-How Series, Total website http://www.total.com/static/en/medias/topic1026/tight-gasreservoirs_2007.pdf, 2006 [19/07/09]

[34] IEA, World Energy Outlook 2009, Technical report, International Energy Agency, 2009.

[35] Mohr SH, Evans GM, Model proposed for world conventional, unconventional gas, Oil and Gas Journal, 105(47), 46-51, 2007

[36] Laherrère JH, Creaming curves \& cumulative discovery at end of 2007 for Africa countries. ASPO France website. 〈http://aspofrance.viabloga.com/files/JL_Africacream_2009.pdf〉 [2.10.10], 2009

[37] Laherrère JH, Natural gas future supply, The Coming Global Oil Crisis website. $\langle$ http://www.oilcrisis.com/laherrere/IIASA2004.pdf $\rangle ; 2004$ [22.11.10]

[38] Aluko N, Coalbed methane extraction and utilisation. Technology Status Report 016, Department of Trade and Industry DTI website 〈www.dti.gov.uk/files9298.pdf〉 [30.08.07], 2001

[39] Boyer CMI, and Qinghao B, Methodology of coalbed methane resource assessment, International Journal of Coal Geology, 35, 349-368, 1998 
[40] Brown M, Are we facing peak gas, In Geological Society Petroleum Evening Meeting.

〈www.bg-group.com/InvestorRelations/Presentations/Documents/BG_Peak_gas_April_2008.pdf〉 [17.07.09], 15th April, 2008

[41] Benneche J, Natural gas projections from EIA and six others, In EIA Energy Outlook, Modelling and Data Conference, 2007

[42] Curtis JB, Potential Gas Committee reports unprecedented increase in magnitude of U.S. natural gas resource bas, PGC Press Release, $18^{\text {th }}$ June Wwww.energyindepth.org/wp-content/uploads/2009/03/potentialgas-committee-reports-unprecedented-increase-in.pdf〉 [18.07.09], 2009

\section{A URR Calculations}

This section contains the Tables of URR information.

Table A.1

Conventional natural gas production peak year and rate estimates

\begin{tabular}{lrrrr}
\hline Reference & Year & $\begin{array}{r}\text { URR } \\
(\text { EJ })\end{array}$ & $\begin{array}{r}\text { Peak } \\
\text { Year }\end{array}$ & $\begin{array}{r}\text { Peak Prod. } \\
(\text { EJ/y })\end{array}$ \\
\hline Edwards [10] & 1997 & 12,200 & 2040 & 115 \\
Al-Jarri [12] & 1997 & 7,400 & 2011 & 108 \\
Al-Fattah [13] & 2000 & 10,560 & $2014-2017$ & 104 \\
Imam [14] & 2004 & 9,680 & 2019 & 93 \\
Guseo [15] & 2006 & 7,700 & $2008-2014$ & 105 \\
Laherrère [16] & 2007 & 10,500 & 2020 & 140 \\
Campbell [5] & 2009 & 10,130 & 2021 & 113 \\
Zhang et al. [11] & 2010 & Unknown & $2030-2035$ & $\sim 137$ \\
\hline
\end{tabular}


Table A.2

Literature conventional natural gas URR estimates in EJ for the world by region[18]

\begin{tabular}{lrrrrrr}
\hline Region & Al-fattah[13] & BGR[19] & Campbell[5] & IEA[34] & Imam[14] & Laherrère[17] \\
\hline Africa & 500 & 1,062 & 673 & 1,112 & 474 & 840 \\
Asia & 840 & 1,656 & 1,048 & 1,260 & 779 & 1,208 \\
Europe & $588^{\mathrm{a}}$ & 1,036 & 649 & $1,000^{\mathrm{a}}$ & 563 & 840 \\
FSU & $3,570^{\mathrm{b}}$ & 7,624 & 2,210 & $5,634^{\mathrm{b}}$ & 3,071 & 2,000 \\
Middle East & 2,625 & 4,116 & 3,318 & 5,004 & 2,437 & 3,000 \\
N. America & 1,995 & 2,752 & 1,601 & 2,372 & 1,652 & 1,575 \\
S. America & 441 & 893 & 630 & 927 & 702 & 840 \\
World & $\mathbf{1 0 , 5 6 0}$ & $\mathbf{1 9 , 1 4 0}$ & $\mathbf{1 0 , 1 3 0}$ & $\mathbf{1 7 , 3 1 0}$ & $\mathbf{9 , 6 8 0}$ & $\mathbf{1 0 , 5 5 0}$ \\
\hline
\end{tabular}

${ }^{a}$ Western Europe

${ }^{\mathrm{b}}$ Eastern Europe + FSU 
Table A.3

Conventional natural gas URR in EJ for the world by country

\begin{tabular}{|c|c|c|c|c|c|c|c|}
\hline Country & Low & $\mathrm{BG}$ & High & Country & Low & $\mathrm{BG}$ & HIGH \\
\hline Algeria & $231^{\mathrm{C}}$ & $231^{\mathrm{C}}$ & $290^{\mathrm{B}}$ & Europe & 697 & 917 & 1036 \\
\hline Angola & $53^{\mathrm{L}}$ & $55^{\mathrm{B}}$ & $55^{\mathrm{B}}$ & FSU & $2310^{\mathrm{L}}$ & $3449^{\mathrm{M}}$ & $7624^{\mathrm{B}}$ \\
\hline Egypt & $105^{\mathrm{L}}$ & $135^{\mathrm{B}}$ & $135^{\mathrm{B}}$ & Iran & $1,208^{\mathrm{C}}$ & $1,503^{\mathrm{B}}$ & $1,503^{\mathrm{B}}$ \\
\hline Libya & $105^{\mathrm{L}}$ & $105^{\mathrm{L}}$ & $88^{\mathrm{B}}$ & Iraq & $131^{\mathrm{C}}$ & $270^{\mathrm{B}}$ & $270^{\mathrm{B}}$ \\
\hline Nigeria & $263^{\mathrm{L}}$ & $263^{\mathrm{L}}$ & $334^{\mathrm{B}}$ & Kuwait & $74^{\mathrm{C}}$ & $74^{\mathrm{C}}$ & $94^{\mathrm{B}}$ \\
\hline Rest & $117^{\mathrm{C}, \mathrm{L}, \mathrm{B}}$ & $126^{\mathrm{C}, \mathrm{L}, \mathrm{B}}$ & $161^{\mathrm{B}}$ & Oman & $63^{\mathrm{C}}$ & $63^{\mathrm{C}}$ & $74^{\mathrm{B}}$ \\
\hline Africa & 873 & 915 & 1062 & Qatar & $1,134^{\mathrm{C}}$ & $1,134^{\mathrm{C}}$ & $1,051^{\mathrm{B}}$ \\
\hline Australia & $231^{\mathrm{C}}$ & $196^{\mathrm{B}}$ & $196^{\mathrm{B}}$ & Saudi Arabia & $478^{\mathrm{C}}$ & $478^{\mathrm{C}}$ & $725^{\mathrm{B}}$ \\
\hline Bangladesh & $55^{\mathrm{B}}$ & $52^{\mathrm{H}}$ & $55^{\mathrm{B}}$ & UAE & $179^{\mathrm{C}}$ & $314^{\mathrm{B}}$ & $314^{\mathrm{B}}$ \\
\hline Burma & $52^{\mathrm{B}}$ & $52^{\mathrm{B}}$ & $52^{\mathrm{B}}$ & Rest & $63^{\mathrm{C}, \mathrm{B}}$ & $90^{\mathrm{C}, \mathrm{B}}$ & $86^{\mathrm{B}}$ \\
\hline China & $210^{\mathrm{C}}$ & $210^{\mathrm{C}}$ & $507^{\mathrm{B}}$ & Middle E. & 3330 & 3926 & 4116 \\
\hline India & $79^{\mathrm{C}}$ & $89^{\mathrm{B}}$ & $89^{\mathrm{B}}$ & Canada & $333^{\mathrm{H}}$ & $333^{\mathrm{H}}$ & $637^{\mathrm{B}}$ \\
\hline Indonesia & $242^{\mathrm{C}}$ & $301^{\mathrm{B}}$ & $301^{\mathrm{B}}$ & USA & $1,313^{\mathrm{J}}$ & $1,313^{\mathrm{J}}$ & $1313^{\mathrm{J}}$ \\
\hline Malaysia & $116^{\mathrm{C}}$ & $173^{\mathrm{B}}$ & $173^{\mathrm{B}}$ & N. America & 1,628 & 1,628 & 2,752 \\
\hline Pakistan & $68^{\mathrm{C}}$ & $85^{\mathrm{B}}$ & $85^{\mathrm{B}}$ & Argentina & $79^{\mathrm{C}}$ & $106^{\mathrm{B}}$ & $106^{\mathrm{B}}$ \\
\hline Rest & $162^{\mathrm{C}, \mathrm{B}}$ & $184^{\mathrm{H}, \mathrm{C}, \mathrm{B}}$ & $251^{\mathrm{B}}$ & Bolivia & $68^{\mathrm{C}}$ & $58^{\mathrm{B}}$ & $58^{\mathrm{B}}$ \\
\hline Asia & 1214 & 1341 & 1656 & Brazil & $21^{\mathrm{C}}$ & $21^{\mathrm{C}}$ & $95^{\mathrm{B}}$ \\
\hline Germany & $50^{\mathrm{C}}$ & $48^{\mathrm{B}}$ & $48^{\mathrm{B}}$ & Mexico & $105^{\mathrm{C}}$ & $142^{\mathrm{B}}$ & $142^{\mathrm{B}}$ \\
\hline Greenland & 0 & $104^{\mathrm{B}}$ & $104^{\mathrm{B}}$ & Trinidad & $53^{\mathrm{C}}$ & $65^{\mathrm{B}}$ & $65^{\mathrm{B}}$ \\
\hline Netherlands & $173^{\mathrm{C}}$ & $173^{\mathrm{C}}$ & $171^{\mathrm{B}}$ & Venezuela & $242^{\mathrm{C}}$ & $242^{\mathrm{C}}$ & $326^{\mathrm{B}}$ \\
\hline Norway & $158^{\mathrm{C}}$ & $265^{\mathrm{H}}$ & $311^{\mathrm{B}}$ & Rest & $78^{\mathrm{C}, \mathrm{B}}$ & $85^{\mathrm{C}, \mathrm{B}}$ & $102^{\mathrm{B}}$ \\
\hline Romania & $58^{\mathrm{C}}$ & $60^{\mathrm{H}}$ & $84^{\mathrm{B}}$ & S. America & 645 & 729 & 893 \\
\hline UK & $131^{\mathrm{C}}$ & $131^{\mathrm{C}}$ & $153^{\mathrm{B}}$ & World & 10,708 & 12,915 & 18,321 \\
\hline Rest & $126^{\mathrm{P}, \mathrm{C}, \mathrm{B}}$ & $136^{\mathrm{P}, \mathrm{H}, \mathrm{B}, \mathrm{C}}$ & $166^{\mathrm{P}, \mathrm{B}}$ & & & & \\
\hline
\end{tabular}


Table A.4

Coalbed methane resources in EJ for the world by continent [18]

\begin{tabular}{|c|c|c|c|}
\hline Continent & Region & Scott and Balin $[22]$ & Rogner[27] \\
\hline Africa & & $28-58$ & $42^{\mathrm{a}}$ \\
\hline \multirow{3}{*}{ Asia } & Australia ${ }^{\mathrm{b}}$ & & 504 \\
\hline & North $^{\mathrm{c}}$ & $678-3,528^{\mathrm{d}}$ & 1,302 \\
\hline & Subcontinent $^{\mathrm{e}}$ & & 42 \\
\hline \multirow{2}{*}{ Europe } & Eastern Europe & & 126 \\
\hline & Western Europe & 169-282 & 168 \\
\hline FSU & & $4,200-16,922$ & 4,242 \\
\hline North America & & $999-4,602$ & 3,234 \\
\hline South America & & $16-34$ & 42 \\
\hline World & & $6,300-25,200$ & 9,702 \\
\hline
\end{tabular}

a Sub-Saharan Africa

b Australia and Japan; Japanese resources are believed to be very small relative to Australian resources

c Vietnam to Mongolia

d All of Asia

e Afghanistan to Bangladesh 
Table A.5

Coalbed methane resources in EJ for the world by country [18]

\begin{tabular}{|c|c|c|c|c|c|}
\hline Country & $\begin{array}{r}\text { Campbell \& } \\
\text { Heaps[5] }\end{array}$ & Aluko[38] & Boyer[39] & $\begin{array}{l}\text { Cramer } \\
\text { et al.[23] }\end{array}$ & $\begin{array}{r}\text { Kuuskraa \& } \\
\text { Stevens[21] }\end{array}$ \\
\hline South Africa & & 37 & $32^{\mathrm{a}}$ & $5-32$ & $95-231^{b}$ \\
\hline Australia & 525 & $297-519$ & $315-525$ & $297-593$ & $525-1,050^{\mathrm{c}}$ \\
\hline China & 1,050 & $1,112-2,039$ & $1,113-1,302$ & $1,260-1,364$ & $735-1,334$ \\
\hline India & & 37 & 32 & $15-74$ & $74-95$ \\
\hline Indonesia & & $<37$ & & $354-476$ & $357-473$ \\
\hline Germany & & 111 & 105 & 19-111 & \\
\hline Poland & & 111 & 105 & $13-115$ & $21-53$ \\
\hline UK & & 93 & 63 & $63-107$ & $210^{\mathrm{d}}$ \\
\hline Turkey & & & & & $53-116$ \\
\hline Russia & 4,200 & $741-4,300^{\mathrm{e}}$ & $630-4,200$ & $1,887-2,928$ & $473-2,100$ \\
\hline Kazakhstan & & & 42 & $44-63$ & $42-63$ \\
\hline Ukraine & & & 63 & $63-2,835$ & 179 \\
\hline Canada & 3,150 & $222-2,817$ & $210-2,835$ & $691-3,204$ & $378-483$ \\
\hline USA & 525 & 408 & $360-435$ & $199-1,809$ & $525-1,575$ \\
\hline Other & & & 32 & $161-177$ & 53 \\
\hline World & 9,450 & $3,169-10,508$ & $3,101-9,769$ & $5,070-13,889$ & $3,717-8,012$ \\
\hline
\end{tabular}

a Southern Africa

b Southern Africa, includes carbonaceous shales

c includes New Zealand

d Western Europe

e FSU 
Table A.6

Coalbed methane URR in EJ for the world by country

\begin{tabular}{|c|c|c|c|c|}
\hline Country & Low & $\mathrm{BG}$ & High & Comments on BG \\
\hline South Africa & $32^{\mathrm{a}}$ & 9 & 5 & Resource from [38] with $25 \%$ recovery \\
\hline Africa & 32 & 9 & 5 & \\
\hline Australia & $126^{\mathrm{b}}$ & 231 & 297 & URR from $[40]$ \\
\hline China & 105 & 315 & 1,261 & Low resource of [23] with $25 \%$ recovery \\
\hline India & 21 & 19 & 15 & High resource of [23] with $25 \%$ recovery \\
\hline Indonesia & 53 & 9 & 354 & Resource from [38] with $25 \%$ recovery \\
\hline Mongolia & & 0 & 1 & Low resource from [23] with $25 \%$ recovery \\
\hline Asia & 305 & 574 & 1,928 & \\
\hline Bulgaria & & 2 & 6 & Resource from [23] with $25 \%$ recovery \\
\hline Czech Republic & & 3 & 2 & High resource of [23] with $25 \%$ recovery \\
\hline Germany & & 26 & 19 & Resource from [39] with $25 \%$ recovery \\
\hline Hungary & & 1 & 6 & High resource of [23] with $25 \%$ recovery \\
\hline Netherlands & & 7 & 30 & Resource from [23] with $25 \%$ recovery \\
\hline Poland & 5 & 26 & 13 & Resource from [39] with $25 \%$ recovery \\
\hline Turkey & 11 & 28 & 111 & Resource from [39] with $25 \%$ recovery \\
\hline $\mathrm{UK}$ & $21^{\mathrm{c}}$ & 16 & 63 & Resource from [39] with $25 \%$ recovery \\
\hline Europe & 37 & 109 & 250 & \\
\hline Kazakhstan & 11 & 11 & 45 & Resource from [39] with $25 \%$ recovery \\
\hline Russia & 210 & 732 & 1,887 & High estimate of [23] with $25 \%$ recovery \\
\hline Ukraine & 26 & 709 & 63 & High estimate of [23] with $25 \%$ recovery \\
\hline FSU & 247 & 1,452 & 1,995 & \\
\hline Canada & 95 & 175 & $788^{\mathrm{d}}$ & URR from [26] \\
\hline USA & 147 & 171 & $210^{\mathrm{e}}$ & URR from $[20]$ \\
\hline North America & 242 & 346 & 998 & \\
\hline Mexico & $11^{\mathrm{f}}$ & 2 & 5 & High resource of [23] with $25 \%$ recovery \\
\hline South America & 11 & 2 & 5 & \\
\hline World & 872 & 2,494 & 5,178 & \\
\hline
\end{tabular}

a All of Southern African URR was assumed to be in South Africa

b All of Australia and New Zealand URR was assumed to be in Australia

c All of Western Europe URR was assumgd to be in the UK

d Assumed Campbell and Heaps (2009) estimate with 25\% recovery

e Produced and proved reserves from [41] probable to speculative resources from $[42]$

${ }^{\mathrm{f}}$ All of South America and Mexico's URR was assumed to be in Mexico 
Table A.7

Shale gas resources in EJ for the world by region

\begin{tabular}{|c|c|c|}
\hline Region & Rogner[27] & Cramer et al.[23] \\
\hline Sub Saharan Africa & 294 & 289 \\
\hline Australia $^{a}$ & 2,478 & 2,429 \\
\hline North Asia ${ }^{b}$ & 3,780 & 3,704 \\
\hline South East Asia ${ }^{c}$ & 336 & 330 \\
\hline Eastern Europe & 42 & 41 \\
\hline Western Europe & 546 & 534 \\
\hline FSU & 672 & 660 \\
\hline Middle East and North Africa & 2,730 & 2,677 \\
\hline North America & 4,116 & 4,034 \\
\hline South America ${ }^{\mathrm{d}}$ & 2,268 & 2,225 \\
\hline World & 17,262 & 16,923 \\
\hline
\end{tabular}

a Australia and Japan; Japan believed to have little resources

b Vietnam to Mongolia

c Burma to PNG

d Includes Mexico 
Table A.8

Shale gas recoverable resources for North America EJ [20]

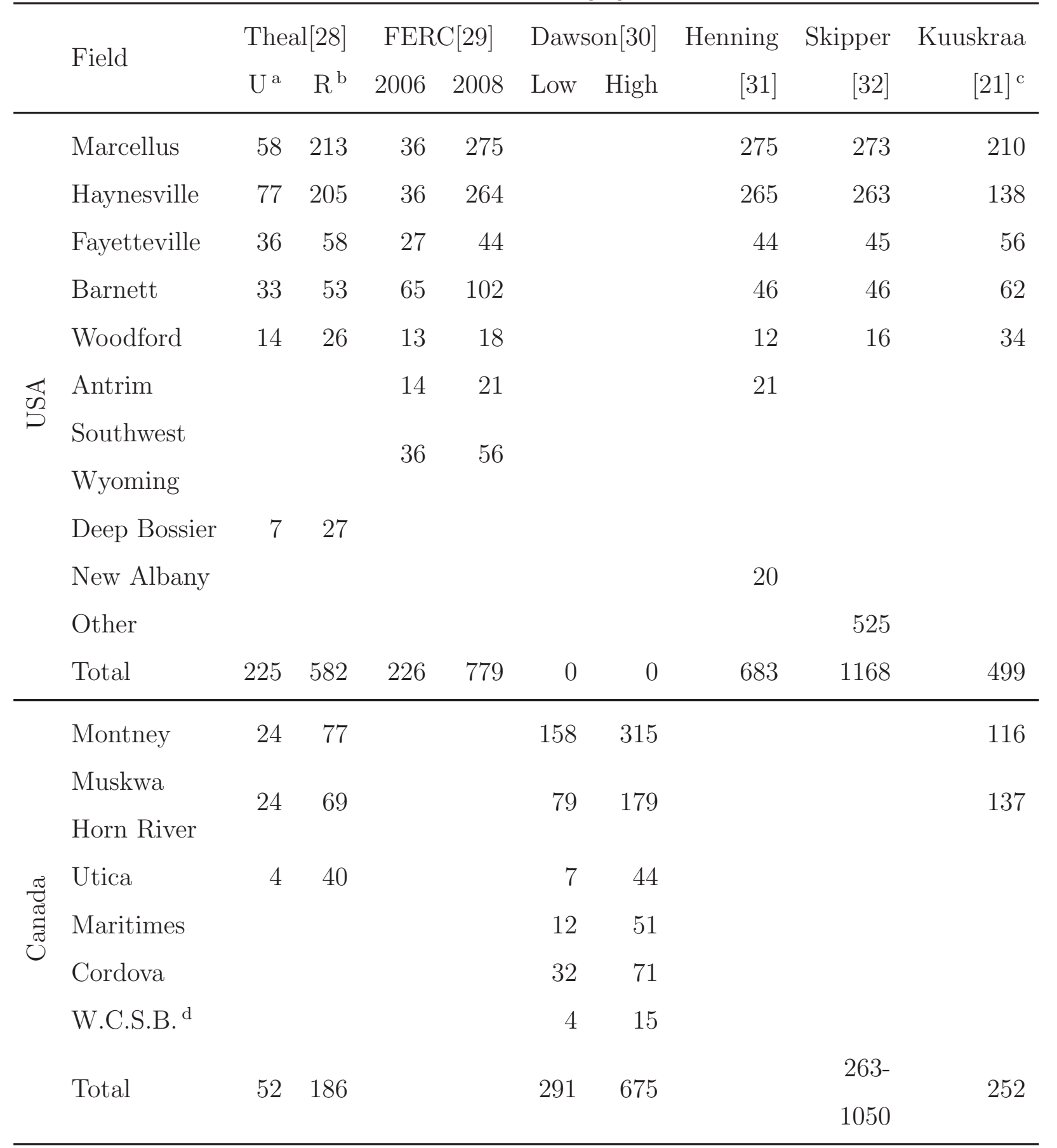

${ }^{a}$ Unrisked

b Risked

${ }^{c}$ Kuuskraa and Stevens, URR values

${ }^{\mathrm{d}}$ Western Canada Sedimentary Basin 
Table A.9

Assumed shale gas URR estimates for North America EJ [20]

\begin{tabular}{llrrr}
\hline Country & basin & Low & BG & HiGH \\
\hline Canada & Montney & 24 & 116 & 315 \\
Canada & Muskwa/Horn River & 24 & 137 & 179 \\
Canada & Utica & 4 & 40 & 44 \\
Canada & Maritimes & 12 & 51 & 51 \\
Canada & Cordova & 32 & 71 & 71 \\
Canada & W.C.S.B. & 4 & 15 & 15 \\
USA & Marcellus & 59 & 210 & 273 \\
USA & Haynesville & 77 & 138 & 263 \\
USA & Fayetteville & 36 & 56 & 58 \\
USA & Barnett & 38 & 62 & 107 \\
USA & Woodford & 14 & 34 & 34 \\
USA & Other USA & 104 & 124 & 525 \\
North America & $\mathbf{4 2 5}$ & $\mathbf{1 0 5 2}$ & $\mathbf{1 9 3 4}$ \\
\hline
\end{tabular}


Table A.10

Shale gas URR in EJ for the Rest of the world based on Rogner [27] and a 15\% recovery

\begin{tabular}{lrrrl}
\hline Country & LOW & BG & HigH & Comments \\
\hline Morocco & 205 & 205 & 205 & $50 \%$ of Middle E. and N. Africa \\
Zaire & 44 & 44 & 44 & All Sub Saharan Africa \\
Africa & $\mathbf{2 4 9}$ & $\mathbf{2 4 9}$ & $\mathbf{2 4 9}$ & \\
Australia & 372 & 372 & 372 & Assumed no resources in Japan \\
China & 567 & 567 & 567 & All of North Asia \\
Thailand & 50 & 50 & 50 & All of South East Asia \\
Asia & $\mathbf{9 8 9}$ & $\mathbf{9 8 9}$ & $\mathbf{9 8 9}$ & \\
Italy & 82 & 82 & 82 & All of Western Europe \\
Poland & 6 & 6 & 6 & All of Eastern Europe \\
Europe & $\mathbf{8 8}$ & $\mathbf{8 8}$ & $\mathbf{8 8}$ & \\
FSU & $\mathbf{1 0 1}$ & $\mathbf{1 0 1}$ & $\mathbf{1 0 1}$ & All of FSU \\
Jordan & 205 & 205 & 205 & $50 \%$ of Middle E. and N. Africa \\
Middle East & $\mathbf{2 0 5}$ & $\mathbf{2 0 5}$ & $\mathbf{2 0 5}$ & \\
Brazil & 340 & 340 & 340 & Assumed all of South America \\
South America & $\mathbf{3 4 0}$ & $\mathbf{3 4 0}$ & $\mathbf{3 4 0}$ & \\
Rest of World & $\mathbf{1 9 7 2}$ & $\mathbf{1 9 7 2}$ & $\mathbf{1 9 7 2}$ & \\
World & $\mathbf{2 3 9 7}$ & $\mathbf{3 0 2 4}$ & $\mathbf{3 9 0 6}$ & By combining with Table A.9 \\
\hline & & & & \\
\hline
\end{tabular}

Table A.11

Tight gas reserves by region $[33]$

\begin{tabular}{lr}
\hline Region & Percentage \\
\hline USA + Canada & $45 \%$ \\
FSU & $12 \%$ \\
Middle East & $7 \%$ \\
China + Australia & $33 \%$ \\
Other & $3 \%$ \\
\hline
\end{tabular}


Table A.12

Tight gas in place in EJ for the world by regions [18]

\begin{tabular}{lrr}
\hline Region & {$[27]$} & {$[23]$} \\
\hline Sub Saharan Africa & 840 & 815 \\
Australia $^{\mathrm{a}}$ & 756 & 741 \\
North Asia $^{\mathrm{b}}$ & 378 & 371 \\
South East Asia $^{\mathrm{c}}$ & 588 & 593 \\
Subcontinent $^{\mathrm{d}}$ & 210 & 222 \\
Eastern Europe & 84 & 74 \\
Western Europe & 378 & 371 \\
FSU & 966 & 964 \\
Middle East and North Africa & 882 & 852 \\
North America & 1,470 & 1,446 \\
South America & \\
World & 1,386 & 1,371 \\
\hline
\end{tabular}

a Australia and Japan; Japan believed to have negligible resources

b Vietnam to Mongolia

c Burma to PNG

d Afghanistan to Bangladesh

e Includes Mexico 
Table A.13

Tight gas URR in EJ [18]

\begin{tabular}{|c|c|c|c|c|c|}
\hline Region & Low & $\mathrm{BG}$ & $\begin{array}{l}\text { Comments } \\
\text { CASE } 1 \& 2\end{array}$ & HigH & $\begin{array}{l}\text { Comments } \\
\text { HIGH }\end{array}$ \\
\hline Algeria & 7 & 19 & 1/3 Other $[33]$ & 43 & $1 / 3$ of ME \& NA $[23]^{a}$ \\
\hline Egypt & & & & 43 & $1 / 3$ of $\mathrm{ME} \& \mathrm{NA}[23]^{\mathrm{a}}$ \\
\hline Nigeria & & & & 122 & Southern Africa [23] \\
\hline Africa & 7 & 19 & & 208 & \\
\hline Australia & 82 & 204 & 1/3 China/Australia ${ }^{\mathrm{b}}$ & 111 & Pacific (OECD) [23] \\
\hline China & 163 & 408 & 2/3 China/Australia ${ }^{\mathrm{b}}$ & 56 & North Asia [23] \\
\hline India & & & & 33 & Subcontinent [23] \\
\hline Indonesia & 7 & 19 & 1/3 Other [33] & 89 & South Asia [23] \\
\hline Asia & 252 & 631 & & 289 & \\
\hline Germany & & & & 14 & $1 / 4$ of W. Europe [23] \\
\hline France & & & & 14 & 1/4 of W. Europe [23] \\
\hline Netherlands & & & & 14 & 1/4 of W. Europe [23] \\
\hline UK & & & & 14 & $1 / 4$ of W. Europe [23] \\
\hline Europe & & & & 56 & \\
\hline FSU & 89 & 222 & {$[33]$} & 156 & FSU + E. Europe [23] \\
\hline Saudi Arabia & 52 & 130 & Middle East[33] & 43 & $1 / 3$ of $\mathrm{ME} \& \mathrm{NA}[23]^{\mathrm{a}}$ \\
\hline Middle East & 52 & 130 & & 43 & \\
\hline Canada & $145[20]$ & $210[20]$ & & 326 & {$[20]$} \\
\hline USA & $431[20]$ & $489[20]$ & & 658 & {$[20]$} \\
\hline North America & 576 & 699 & & 984 & \\
\hline Argentina & 7 & 19 & 1/3 Other $[33]$ & 69 & $1 / 3$ of S. America [23] \\
\hline Mexico & & & & 69 & $1 / 3$ of S. America [23] \\
\hline Venezuela & & & & 69 & $1 / 3$ of S. America [23] \\
\hline South America & 7 & 19 & & 207 & \\
\hline World & 983 & 1,720 & & 1,943 & \\
\hline
\end{tabular}

a Middle East and North Africa

b [33] indicates most tight gas resides in Russia/China and North America, hence the bias towards China split 


\section{B Dynamic Demand}

The Dynamic demand is the same as the Static demand except that $\tilde{D}(t)$ is modified as described:

$$
\tilde{D}(t)= \begin{cases}\tilde{D}(t-1)(1-0.15 G(t)) & ; \text { if } \tilde{D}(t-1)>62 \& \breve{D}(t)>62 \\ {[62-\tilde{D}(t-1) 0.15 G(t)]} & ; \text { if } \tilde{D}(t-1) \leq 62 \& \breve{D}(t)>62 \\ \tilde{D}(t-1)\left[e^{0.02502}-0.15 G(t)\right] & ; \text { if } \breve{D}(t) \leq 62\end{cases}
$$

with

$$
\breve{D}(t)=\tilde{D}(t-1)\left(e^{0.02502}-0.15 G(t)\right)
$$

$G(t)$ is the fractional difference between supply and demand defined as:

$$
G(t)=\frac{D(t-1)-P(t-1)}{P(t-1)}
$$

where $P(t-1)$ is the world's production of natural gas in the year $t-1$. 
(a) Static Low

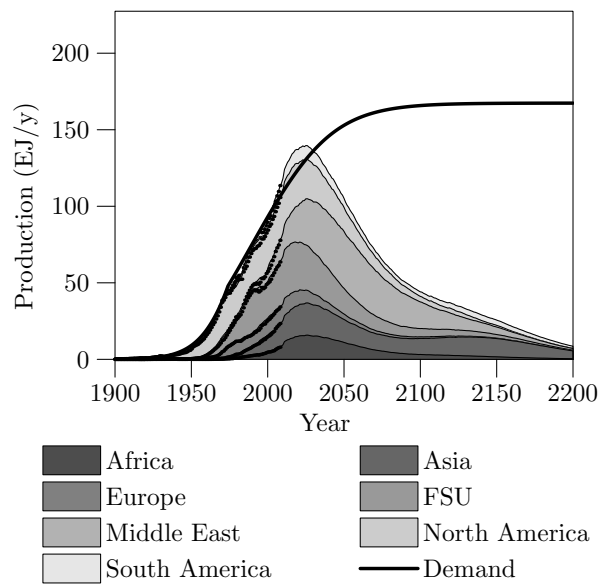

(c) Static BG

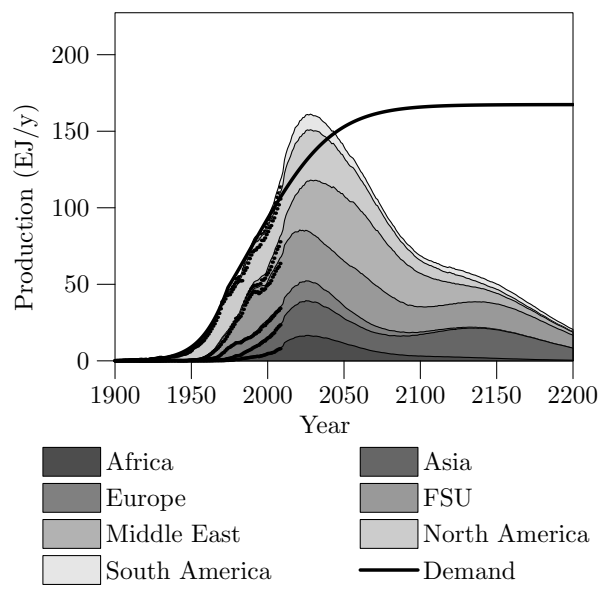

(e) Static High

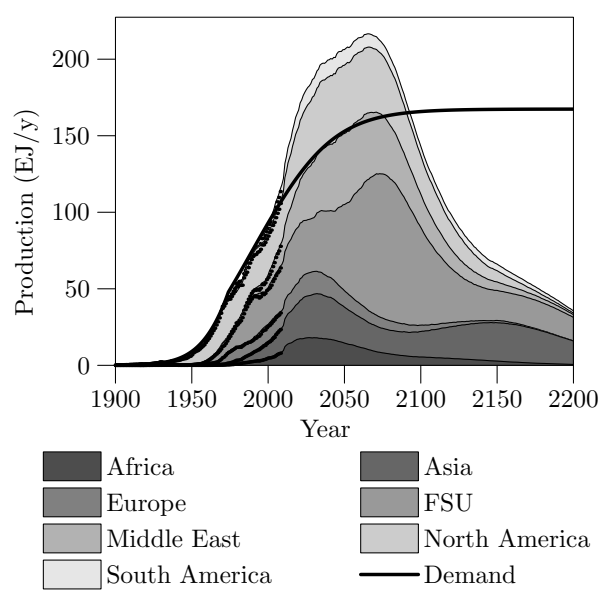

(b) Dynamic Low

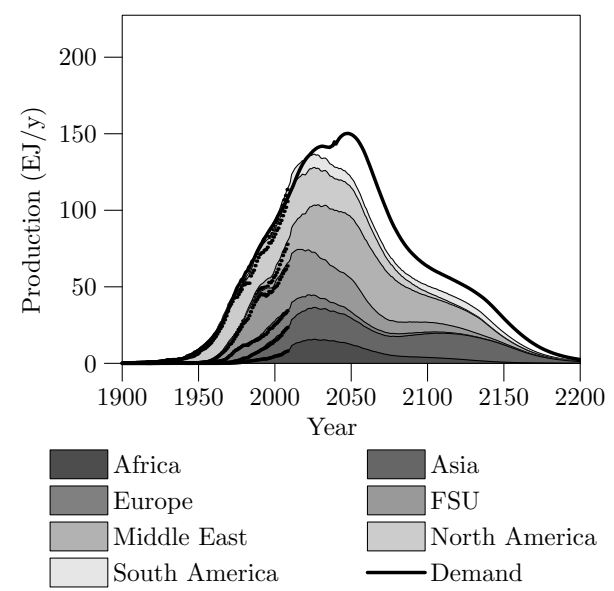

(d) Dynamic BG

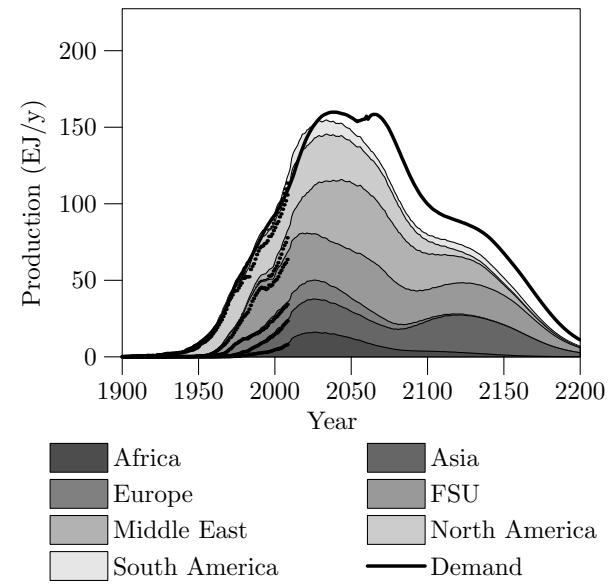

(f) Dynamic High

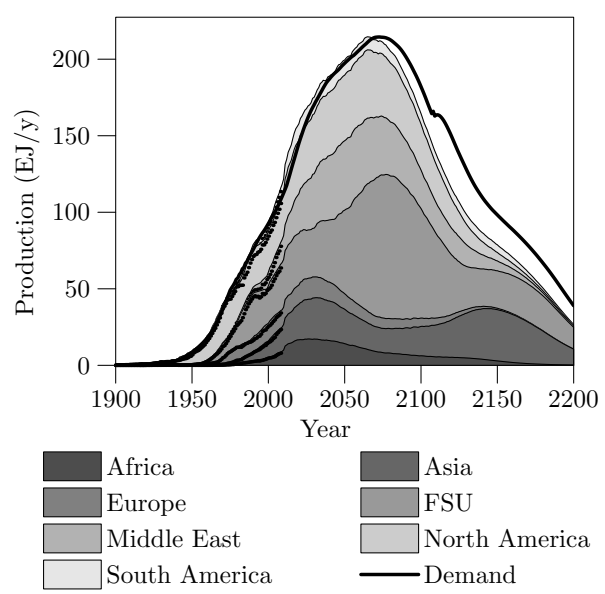

Fig. B.1. Natural gas projections for the world by continent 
(a) Static Low

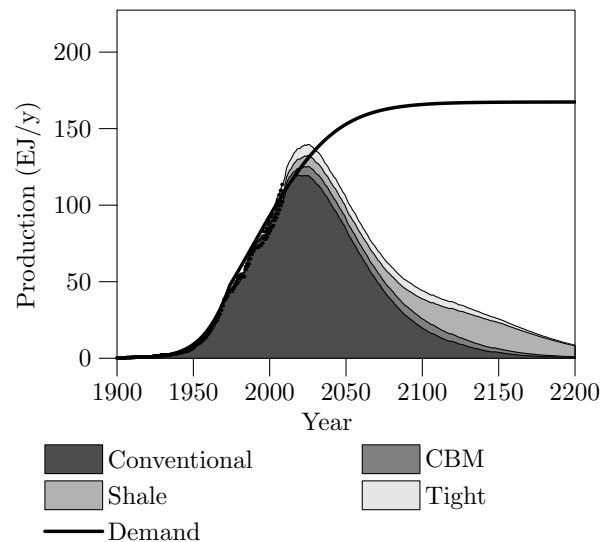

(c) Static BG

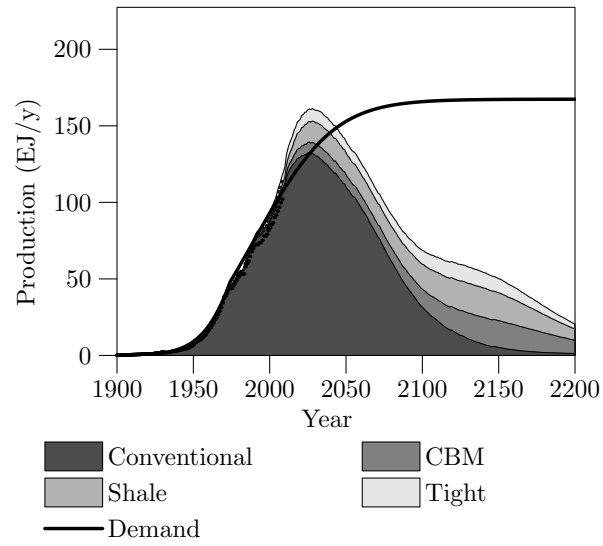

(e) Static High

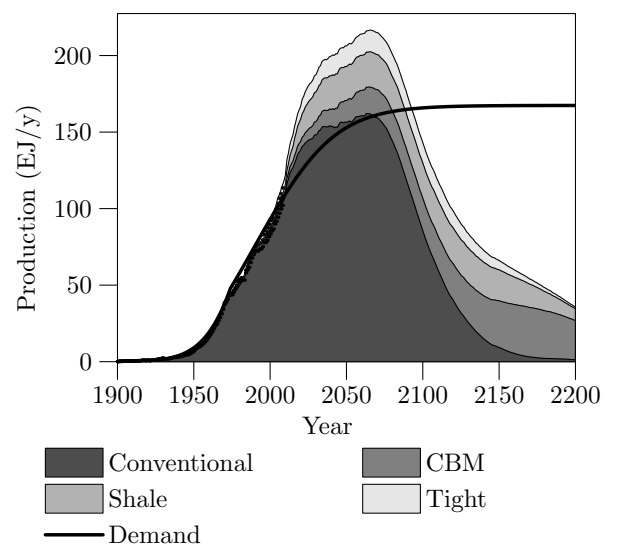

(b) Dynamic Low

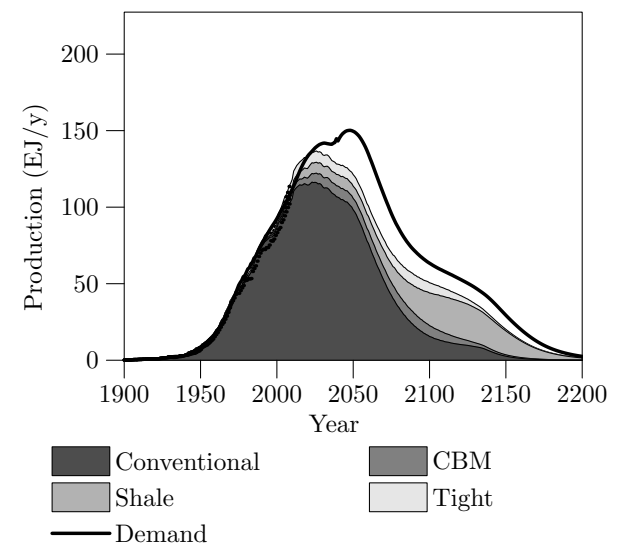

(d) Dynamic BG

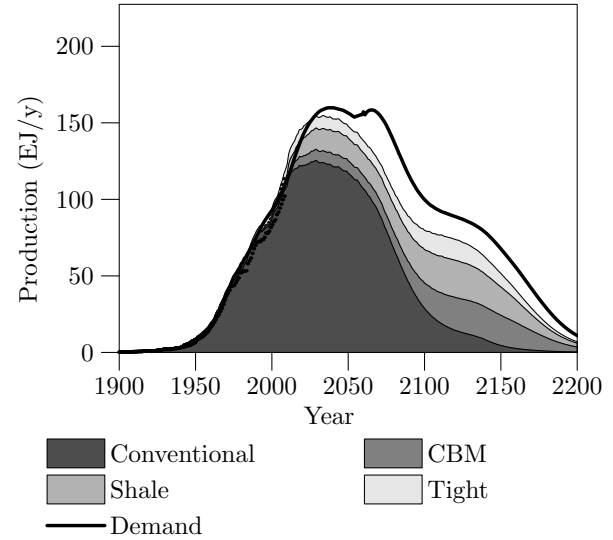

(f) Dynamic High

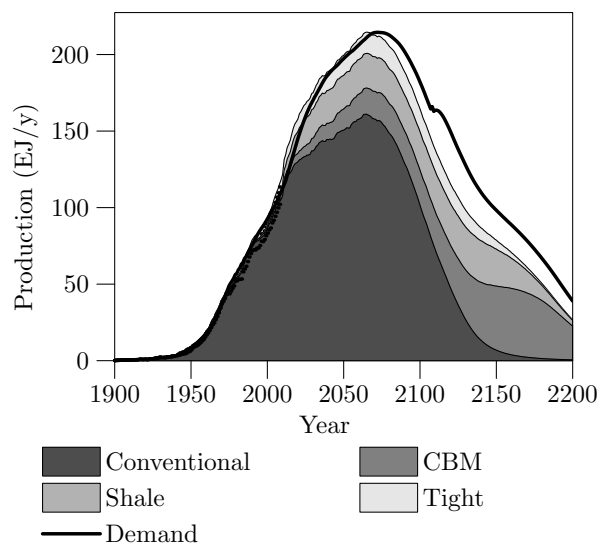

Fig. B.2. Natural gas projections for the world by type 